\section{Pengembangan Mamaca di Pamekasan Madura sebagai Penguatan Harmoni Kehidupan Sosial}

\section{Supadma ${ }^{1}$}

Jurusan Tari, Fakultas Seni Pertunjukan, Institut Seni Indonesia Yogyakarta

I Wayan Dana

Jurusan Tari, Fakultas Seni Pertunjukan, Institut Seni Indonesia Yogyakarta

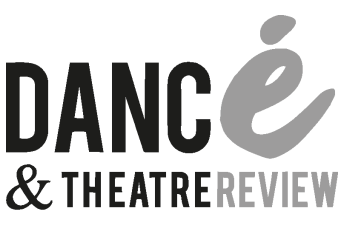

jurnal tari, teater, dan wayang volume 4 number 2 ,

November 2021

page $95-105$

\begin{abstract}
The Development of Mamaca in Pamekasan Madura as Strengthening Harmony of Social Life. This study aims to develop one of the traditional performing arts, namely Mamaca in Pamekasan Regency, Madura Island, which is abandoned, especially by the local younger generation. Mamaca, which emphasizes the nobility of values and norms in its form and implementation, is capable of strengthening the nation's character and the harmony of social life. Thus, this research is an effort to reconstruct local cultural and community values. Seeing its essential role, this research on Mamaca will be carried out in three years. Mamaca presents the values of local wisdom and uses the hermeneutic approach. The reinforcement is designed in the form of new Mamaca choreography according to the spirit of the times. It also reflects the will of the supporting community but still does not leave its primary source. The design of the form of presentation is based on an emic and ethical point of view, namely using a choreographic approach by involving the ideas of local artists or actors. The "new" Mamaca choreography was introduced to students of several elementary schools, as well as to existing performing arts groups. By introducing and teaching it to young children, it is hoped that the stronger and longer roots will be planted for growth. Its introduction and application are followed up by contesting it to motivate others in arts and to promote it to a broader audience, Mamaca can be developed outside its original area, but with similar traditional performing arts. Based on this plan, further development of choreography is also designed to be taught to children and adapted to their distribution area.
\end{abstract}

Keywords: mamaca; Pamekasan Madura; local wisdom; national character; social harmony

\section{Pendahuluan}

Mamaca dalam bahasa Madura berarti membaca. Para pelakunya secara bergantian membaca dan melagukan syair-syair dari naskah tertentu. Naskah yang dibaca ini berbahasa Jawa Baru, bertulis tangan, dan beraksara Arab Pégon. Pembaca naskah disebut pamaos. Salah seorang pelakunya bertindak sebagai panegghes atau penyampai makna isi naskah yang dibaca oleh pamaos (Kusmayati dan Sayuti, 2014: 182-190 dan Akhyar, dkk. 2010: 27, 212, dan 213).

Naskah-naskah yang dibaca dalam Mamaca memuat sebagian wiracarita Mahabharata, Ramayana, dan kisah para nabi dalam agama Islam. Cara yang dilakukan untuk memilih atau menentukan sumber bacaan bermacam-macam. Kadang-kadang tuan rumah atau penyelenggara perhelatan yang

$1 \quad$ Alamat korespondensi: Jurusan Tari, Fakultas Seni Pertunjukan, Institut Seni Indonesia Yogyakarta, Jalan Parangtritis Km 6,5 Sewon Yogyakarta 55185. HP.: 081328891770. 
memilih cerita dari naskah yang akan dibaca. Kelompok Mamaca yang akan melaksanakan kegiatan tersebut, khususnya yang akan membacakannya, memilihkan naskah maupun ceritanya. Tidak jarang, tuan rumah atau penyelenggara perhelatan memohon kepada seseorang yang dituakan (bahasa Madura: ро seppo) untuk memilihkannya. Seseorang atau keluarga yang sedang melaksanakan perhelatan akan merasa tersanjung dan terberkahi apabila po seppo berkenan untuk memilihkan cerita dari suatu naskah yang akan dibacakan secara khusus. Di sisi sebaliknya, po seppo merasa dituakan dan dihormati keberadaannya di antara warga masyarakat dengan permohonan itu. Penentu cerita biasanya akan menyesuaikan isi cerita dengan kegiatan yang sedang dilaksanakan.

Kearifan local, seperti norma setempat, nilai kebaikan, serta petuah kebijaksanaan, dikumandangkan ketika Mamaca dilaksanakan. Doa secara Islam mengawali dan menutup kegiatan tersebut. Di samping itu, ajaran Islam juga disisipkan di dalamnya, meskipun cerita yang dikisahkan mengalir dari epos Ramayana ataupun Mahabharata. Pada dasarnya, Mamaca merupakan bentuk seni pertunjukan yang bersumber dari naskah-naskah yang bersifat didaktis moralitas yang memperoleh sentuhan kuat dari budaya Islam (Kusmayati dan Sayuti, 2014: 184).

Mamaca dipertunjukankan oleh sekitar 10-20 oranglelakidewasa.Merekamengenakan pakaian sehari-hari dan duduk bersila saling berhadapan dalam suatu pola lantai lingkaran. Syair-syair dilagukan bergantian atau bersama-sama. Pelaksanaannya dapat diiringi atau tanpa suara instrumen musik apa pun yang mengiringinya (Kusmayati dan Sayuti, 2010: 61-69 dan Akhyar, dkk. 2010: 212-213). Biasanya Mamaca dilakukan pada saat upacara daur hidup, seperti pernikahan, khitan, rokat atau ruwatan, dan tujuh bulan usia kehamilan. Peringatan hari-hari besar keagamaan maupun nasional seringkali juga dikhidmatkan dan dimeriahkan dengan Mamaca. Peringatan Maulud Nabi Muhammad
SAW dan Isra Miraj Nabi Muhammad SAW merupakan dua di antara hari-hari besar keagamaan yang diperingati dengan menyajikan Mamaca. Selain itu, peringatan Hari Ulang Tahun Kemerdekaan RI adalah salah satu hari besar nasional yang diperingati dengan menghadirkan Mamaca. Penampilan Mamaca juga terkadang muncul pada acara pemenuhan nadar karena terbebas dari sakit atau mara bahaya.

Saat ini, Mamaca mulai ditinggalkan oleh sebagian besar masyarakatnya. Anak-anak muda tidak banyak terlihat, baik sebagai pelaku maupun penontonnya. Bermacammacam alasan dan latar belakang menjadi penyebab fenomena ini. Tinggallah orangorang tua yang kebanyakan melanjutkan tradisi ini. "Eman kalau peninggalan leluhur yang bernilai adiluhur tidak ada yang meneruskan. Padahal isinya bagus". Demikian Pak Haji Sastro menyampaikan dengan logat Madura yang kental (wawancara 29-30 April 2017). Pak Haji Sastro adalah seorang atau bahkan satu-satunya tokoh Mamaca yang dengan gigih dan sangat bersemangat memperjuangkan keberlanjutannya. Dengan setia dihadirinya waktu berlatih Mamaca dan pergelarannya. Selalu diluangkannya waktu untuk kegiatan Mamaca.

Dalam konteks serupa dengan fenomena Mamaca yang mulai ditinggalkan, diperoleh gambaran bahwa masyarakat urban [tidak terkecuali anak-anak muda Pamekasan] menganggap bahwa kebudayaan [kesenian] tradisi ketinggalan zaman sehingga mereka lebih mengacu pada modernitas yang dipandang sebagai suatu kemajuan (Raditya, 2014: 118; Kuswarsantyo, 2014: 105-106). Mereka mulai meninggalkan seni pertunjukan tradisi miliknya.

Kekurangpedulian sebagian warga masyarakat [terutama kalangan muda] untuk merawat dan melanjutkan beragam seni budaya [seni pertunjukan] merupakan salah satu indikasi pemahaman terhadap nilai-nilai seni budaya masyarakat semakin rentan. Seni budaya lokal yang mencitrakan masyarakat 
pemiliknya mengalami perubahan bahkan semakin terbenam oleh budaya baru yang dianggap modern (Kuswarsantyo, 2014: 105106). Seni pertunjukan tradisi, seperti Mamaca merupakan aset non-bendawi yang penting bagi bangsa Indonesia. Keanekaragaman dan keunikannya tidak hanya dikenal oleh bangsa Indonesia sendiri, tetapi sudah secara luas mendunia. Peran pentingnya di dalam kehidupan masyarakat penyelenggaranya tidak dapat terbantahkan. Oleh karena itu, perlu ditelusuri, alasan Mamaca tidak diminati oleh kalangan anak-anak, pemuda, dan cara atau strategi untuk diminati kembali.

Berdasarkan kajian pustaka dan pengamatan sementara ketika mengadakan penjajakan awal di lapangan, ada dugaan bahwa Mamaca mulai ditinggalkan masyarakat, terutama oleh generasi muda. Hal ini dimungkinkan terjadi karena tampilannya kurang menarik dan belum ada upaya untuk membuat menjadi menarik. Upaya yang perlu segera dilakukan adalah membuat tampilannya menarik, terutama bagi anak-anak. Anak-anak diutamakan dengan pertimbangan bahwa semakin dini pengenalannya, maka akan semakin lama ingatan tersimpan dan melekat mengenai sesuatu yang disampaikan.

Tampilan dalam penyajian yang menarik dapat dilakukan dengan cara merancang koreografi baru, pelatihan, dan melombakannya. Namun sebelum melakukan itu semua, tentu perlu diketahui dulu normanorma serta nilai-nilai kearifan lokal yang menjadi muatan Mamaca. Dengan cara seperti ini dapat dirancang strategi untuk menumbuhsuburkan Mamaca.

Dua jenis penelitian yang saling berhubungan dipilih untuk kepentingan penelitian ini. Masing-masing adalah jenis analitikkualitatif dan jenis perancangan koreografi. Penelitian analitik-kualitatif dimaksudkan untuk menganalisis, termasuk menyeleksi, mengklasifikasi, mereduksi data kualitatif, dan pada giliran akhirnya untuk mendeskripsikan hasil analisis. Jenis penelitian ini dipandang tepat untuk mencermati serta menganalisis fenomena sosial-budaya yang terjadi. Seni pertunjukan dan perilaku masyarakatnya merupakan data kualitatif yang akan dianalisis berdasarkan pendekatan fakta sosial.

Jenis penelitian kedua adalah analisis koreografi. Jenis penelitian ini digunakan untuk memberi sentuhan 'baru' terhadap aspek-aspek Mamaca yang sudah ada. Kegiatan ini merupakan dasar penyusunan alternatif pengembangan bentuknya sebagaimana direncanakan.

Tahap-tahap dilalui dengan materi yang bersumber utama pada cerita dari naskah yang sudah dipilih. Cerita yang dipilih disesuaikan dengan kebutuhan, yaitu yang ditujukan untuk anak-anak usia Sekolah Dasar. Bentuk tembang yang digunakan juga yang sederhana. Dalam hal ini tingkat kesulitan harus menjadi pertimbangan. Pada tahap awal ini penekanannya adalah agar anak-anak menyukainya.

Wilayah penelitiannya di Daerah Tingkat II Kabupaten Pamekasan. Survei awal menengarai bahwa kelangsungan seni pertunjukan ini kurang menggembirakan. Oleh karena itu, kesenian ini perlu diteliti dan ditumbuhsuburkan. Pilihan lokasi penelitian juga mempertimbangkan letak geografis Pamekasan yang diapit oleh Daerah Tingkat II Kabupaten Sumenep, Sampang, dan Bangkalan. Langkah demikian dimaksudkan untuk strategi agar wilayah-wilayah yang mengapitnya juga akan menerima pengaruh dan dampak positif dari perlakuan yang diterapkan pada Pamekasan sebagai wilayah kajian penelitian.

Berdasarkan hasil observasi awal, ada beberapa desa yang tercatat memiliki kelompok seni Mamaca di Kabupaten Pamekasan, antara lain: Desa Bentar, Kecamatan Larangan; Desa Blumbungan, Kecamatan Larangan; Desa Jalmak, Kecamatan Pamekasan; Desa Murtajih, Kecamatan Pademawu; Desa Bunder, Kecamatan Pademawu; Desa Sumedangan, Kecamatan Pademawu; Desa Ceguk, Kecamatan Tlanakan; Desa Tlesa, Kecamatan Tlanakan; Desa Larangan Tokol, Kecamatan Tlanakan.

Dari sejumlah desa yang memiliki kelompok seni Mamaca, kelompok yang 
masih aktif melaksanakan kegiatan latihan maupun pertunjukan adalah kelompok seni Mamaca Desa Jalmak, Kecamatan Pamekasan. Kelompok ini diberi nama Rukun Sampurna. Kelompok Rukun Sampurna dijadikan mitra dalam penelitian ini untuk melestarikan dan mengembangkan seni Mamaca di Pamekasan.

Tercatat bahwa anggota kelompok seni Mamaca Rukun Sampurna hingga kini terdiri dari: H. Sastro (66 tahun), Saleh Muchsin (50 tahun), Suparno (56 tahun), Robby (20 tahun), Bur Nurdin (47 tahun), Wahyudi (45 tahun), Suparno (63 tahun), Asmarah (83 tahun), Abdul Rahmat (40 tahun), Asari (69 tahun), dan Sakur (52 tahun).

Informan dipilih berdasarkan kebutuhan dan disesuaikan dengan kompetensinya. Untuk memperoleh data yang berhubungan dengan bentuk penyajian Mamaca dengan berbagai aspeknya, beberapa orang pendukungnya diminta untuk bersedia menjadi informan. Pendukung dalam konteks ini dimengerti sebagai pelaku, penyelenggara atau penyandang dana, dan penonton atau penikmatnya.

Di antara para informan akan dipilih 3-5 orang yang didudukkan sebagai narasumber atau sumber utama. Narasumber adalah orang-orang yang dituakan dan memiliki peran khusus dalam masyarakat atau tokoh di bidang seni pertunjukan yang diteliti. Narasumber diharapkan terdiri dari orangorang tertentu yang pernah menyaksikan atau pernah melakukan sendiri Mamaca tersebut. Kedekatannya dengan materi penelitian tidak pernah diragukan.

Berangkat dari studi lapangan dan informasi masyarakat serta muatan referensi, ditentukan bahwa H. Sastro (66 tahun), Saleh Muchsin (50 tahun), dan Suparno (63 tahun) dijadikan sebagai narasumber utama. Mereka merupakan orang-orang pilihan yang mengetahui bermacam-macam peristiwa penting yang berkaitan dengan seni pertunjukan Mamaca. Diketahui bahwa mereka bertiga pernah menyaksikan, melaksanakan sendiri sebagai seniman pelakunya, dan sekaligus mengelola kehidupannya. Kepada merekalah diharapkan dapat dikemukakan sejumlah pertanyaan pokok dan didapatkan penjelasan serta jawabannya. Pada kenyataannya, mereka adalah orang-orang handal, baik sebagai seniman pelaku maupun aktif menggerakkan seni Mamaca di Pamekasan dalam berbagai event.

Data pada tahap awal dikumpulkan secara kumulatif dari studi pustaka melalui hasil penelitian yang pernah dilakukan oleh para peneliti terdahulu. Pengumpulan datanya adalah dengan cara melacak tulisan-tulisan ilmiah, baik berupa buku, jurnal, makalah, maupun penelitian terdahulu terutama yang sudah dipublikasikan. Dapat dikedepankan beberapa pustaka yang langsung maupun tidak langsung berkaitan dengan inti Mamaca, seperti tulisan Hélène Bouvier, yang diterbitkan tahun 2002 berjudul Lebur: Seni Musik dan Pertunjukan dalam Masyarakat Madura.

Dari studi pustaka dilanjutkan dengan pengamatan terhadap fenomena yang terjadi di lapangan. Sebagian besar data dapat diperoleh pada waktu di lapangan, melalui wawancara dengan narasumber, dan dari semua informan. Ketika berada di lapangan, peneliti menempatkan diri sebagai participant observer atau pengamat yang turut berpartisipasi dalam bermacammacam kegiatan masyarakat, utamanya kegiatan Mamaca. Peneliti membaur di antara pendukung seni pertunjukan tersebut dimulai sejak mereka berkegiatan dalam kehidupan sehari-hari, berproses menyiapkan pertunjukan, sampai dengan pascapertunjukan.

Pada hari Sabtu-Minggu, 29-30 April 2017 dilakukan studi lapangan dengan mengikuti kegiatan kelompok Mamaca Rukun Sempurna. Kelompok tersebut mengadakan pertemuan-pertemuan dan pelatihan yang bertempat di rumah Bapak H. Sastra di Desa Jalmat Pamekasan, Madura. Perilaku ini dijalankan sebagai participant observer dengan mengusung harapan agar memperoleh data primer dan akurat. 
Kegiatan peneliti membaur ke dalam kehidupan masyarakat, terutama ketika berkesenian secara simultan dengan wawancara yang dilakukan terhadap narasumber. Wawancara mendalam menjadi salah satu metode atau cara menggali data otentik dan seluas mungkin melalui narasumber. Data dari narasumber digunakan untuk mengelaborasi dan mengkomparasi data yang berasal dari sumber-sumber lain. Wawancara merupakan suatu metode yang digunakan untuk mengkaji seni, khususnya seni pertunjukan dengan bermacam-macam aspeknya yang unik. Wawancara secara terstruktur dan tidak terstruktur disesuaikan dengan kondisi informan dan situasi pada waktu itu.

Keterbatasan kehadiran peneliti dalam bermacam-macam kegiatan pada waktu yang sama di lapangan sangat terbantu oleh kehadiran dan peran informan. Informan diharapkan dapat menyampaikan berbagai data yang tidak dapat terjangkau langsung oleh peneliti. Di samping itu, waktu untuk mengikuti kegiatan kelompok Mamaca sangat terbatas, sehingga komunikasi dengan mereka dilanjutkan melalui SMS (shot masssege system), WhatsApp, dan telepon. Para narasumber bersedia dihubungi melalui telpon, jika ada hal-hal yang dipandang penting dan substansif untuk didiskusikan, seperti strategi pelestarian maupun meregenerasi pelaku seni Mamaca.

Analisis data dimulai dengan mengumpulkan seluruh data yang didapatkan melalui studi pustaka, pengamatan di lapangan, wawancara mendalam dengan narasumber, dan laporan dari informan. Penyajian Mamaca dan aspek-aspeknya yang direkam secara audio-visual dicermati berulang-ulang. Dengan demikian, pengamatan terhadap data yang diperlukan dapat lebih cermat. Analisis data terhadap aspek-aspek bentuk pertunjukan cenderung dilakukan dengan sudut pandang etik dan sudut pandang emik tetap diperhatikan.

Ketika menganalisis data yang berhubungan dengan tradisi, norma, dan nilai yang menjadi muatan di balik sosok fisiknya, sudut pandang emik digunakan bersama dengan etik. Pandangan masyarakat pendukungnya yang menjadi landasan pendekatan emik sangat diperlukan dan tidak ditinggalkan. Hal ini dimaksudkan sebagai upaya untuk mempertanggungjawabkan penjelasan mengenai bermacam-macam norma dan nilai yang tersirat dari ungkapan wujudnya.

Ketika merancang Mamaca bentuk 'baru', digunakan pendekatan koreografi. Perancangan koreografi memberikan rambu-rambu yang mengarahkan pada tujuannya. Ramburambu tersebut merupakan petunjuk teknis untuk menyusun bentuk seni pertunjukan tertentu, terutama mengenai tahap-tahap yang harus dilalui ketika proses berlangsung.

Menurut Saleh Muchsin (50 tahun), untuk merancang koreografi 'baru' Mamaca, terdapat beberapa hal yang perlu dipertimbangkan. Pertimbangan tersebut mengacu, antara lain: peminat generasi pelaku, dukungan keluarga, dan budaya lingkungan setempat. Kini, pelajaran Mulok (muatan lokal) di Sekolah Dasar bagi peminat yang mau belajar Mamaca menjadi pelajaran pilihan kesenian. Secara spesfik, dibutuhkan seorang guru yang memiliki keterampilan Mamaca yang memadai. Di sisi lain, harus ada anak-anak atau siswa yang memiliki keinginan belajar Mamaca. Ada kalanya, keluarga kurang atau bahkan tidak mendukung karena terkait kuatnya budaya 'fanatisme' sempit yang memandang kegiatan Mamaca sebagai aktivitas 'tabu' (Wawancara, 16 Oktober 2017).

\section{Pembahasan}

\section{H. Sastro: Penjaga dan Penggerak Mamaca}

Penjaga dimaksudkan seseorang yang bertugas sebagai penyelamat. Dia mempertahankan sekuat tenaga untuk dapat mewariskan seni Mamaca dari generasi kini untuk generasi berikutnya. H. Sastro (66 tahun) sebagai penjaga seni Mamaca mengutamakan sisi penerusan agar tidak punah oleh kuatnya 
arus globalisasi yang melanda berbagai aspek kehidupan.

Penggerak merupakan energi yang mendorong H. Sastro sebagai 'penjaga' sehingga seni Mamaca dapat terus hidup di tengah-tengah masyarakat penyangganya. Memaca disajikan dalam berbagai kegiatan, termasuk dipelajari oleh siswa-siswa SD (Sekolah Dasar) sebagai pelajaran kesenian atau mulok (muatan lokal). Peran penjaga dan penggerak memberikan penekanan pada $\mathrm{H}$. Sastro untuk mengembangkan seni Mamaca di Pamekasan sesuai jiwa masyarakat setempat.

H. Sastro lahir di Pamekasan Madura 11 Juli 1951 dari seorang ibu bernama Rapiah dan ayah bernama Kamsito. Ia lahir sebagai anak bungsu dari empat orang bersaudara, 3 laki-laki dan 1 orang perempuan. Tidak satu pun di antara saudaranya yang menekuni kesenian musik tradisi sebagaimana dirinya. Peran ayah sangat menentukan minatnya di dunia kesenian, khususnya seni sastra Madura yang diimplementasikan ke dalam seni pertunjukan Mamaca.

Kini, ia dikenal di Pamekasan sebagai ahli dalam bidang sastra dan adat budaya Madura yang sejak muda ditekuninya. Ia berupaya menyisipkan nilai-nilai kearifan lokal ke dalam syair-syair tembang anak-anak dan macapat yang digubahnya. Gubahannya menjadi materi pembelajaran di tingkat Sekolah Dasar. Ketekunan mempelajari sastra dan tembang mengantarnya untuk studi lanjut di Sekolah

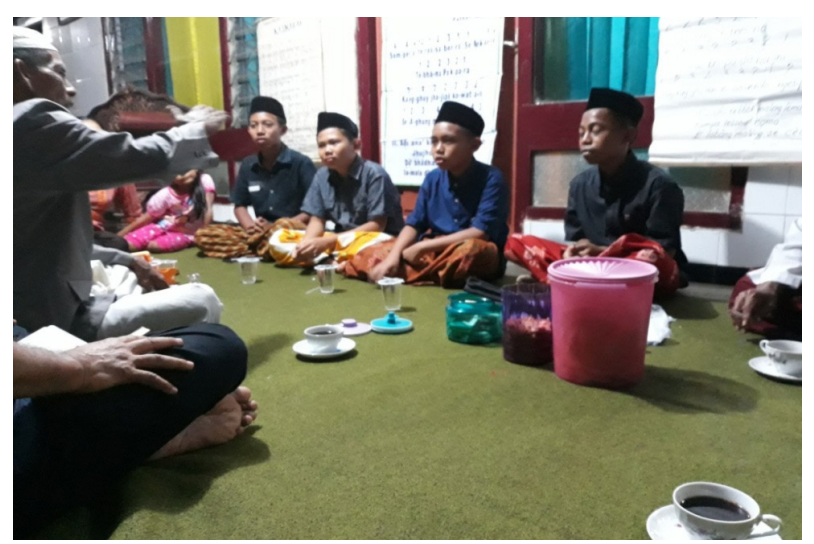

Gambar 1. H. Sastro memberi aba-aba (komando) agar menyamakan tinggi-rendah nada/suara dalam melagukan Mamaca secara bersamaan. (Dokumentasi: I Wayan Dana dan Supadma, 2018)
Tinggi Wilwatikta Surabaya. Di Perguruan Tinggi Seni ini, ia memperdalam sastra dan teknik penyajian Mamaca gaya Pamekasan. Di samping itu, ia berkesempatan pula untuk mempelajari tembang macapat yang hidup di Jawa pada umumnya. Ketekunannya di dunia seni budaya memberikan dukungan yang kuat dan bagus untuk kariernya sebagai guru Sekolah Dasar.

Sejak purna tugas sebagai Pegawai Negeri Sipil pada Juli 2011, H. Sastro memiliki waktu lebih banyak untuk lebih menekuni, menghayati, dan memperdalam sastra Mamaca, utamanya tradisi Pamekasan. Kelompok Rukun Sampurna yang dibentuknya terus didorong untuk menarik minat anakanak muda dan diperkenalkan melalui pembelajaran sastra Madura. Tidak ada kata lelah untuk kegiatan yang dilakukannya ini.

Kelompok tersebut biasanya mengadakan latihan Mamaca setidak-tidaknya seminggu sekali, yaitu setiap Sabtu malam setelah

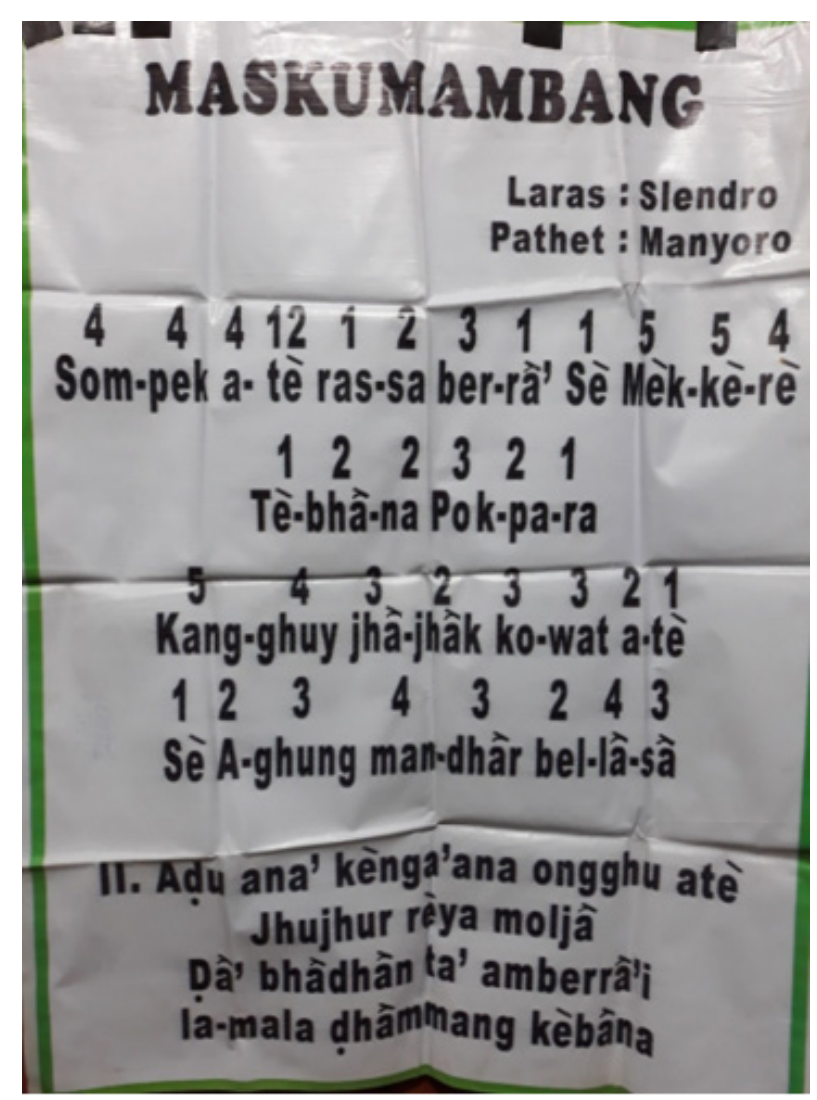

Gambar 2. Tembang Maskumambang dengan "Notasi Kepatihan" agar peserta didik bisa belajar Mamaca sendiri melalui pembacaan notasi. (Dokumentasi: I Wayan Dana dan Supadma, 2018) 
sembahyang Isya bertempat di rumah anggota kelompok. Kegiatan kesenian dilakukan sambil arisan. Pada kesempatan tersebut, H. Sastro [dengan rendah hati mengatakan] berlatih Mamaca. Akan tetapi, sebenarnya ia juga memberikan pelatihan dengan cara memberikan contoh kepada anggota perkumpulan yang belum mahir melakukannya.

Saat ini, ia aktif dan dipercaya sebagai Tenaga Pengajar Luar Biasa di Universitas Madura Pamekasan (UNIRA) untuk mengampu Mata Kuliah Sastra Madura. Seperti dikatakannya bahwa ia tampaknya digariskan untuk mencintai dan menekuni bidang seturut namanya, yaitu sastra. Pendamping setianya juga memiliki nama yang mendekati nama dirinya, yaitu Surati. Surat atau serat tidak lain adalah bahasa halus layang yang berisi karya sastra (wawancara dengan H. Sastro di Pamekasan, 30 April 2017).

Kecintaan H. Sastro terhadap sastra yang ditembangkan dalam bentuk Mamaca mengantar kariernya dan membuatnya semakin dikenal di lingkungan masyarakat Pamekasan. Tahun 1985, ia diminta oleh Dinas Pariwisata Propinsi Jawa Timur sebagai Tim Pergelaran Pesona Madura dari Pamekasan yang disajikan di Graha Wana Bhakti, Taman Ismail Marzuki, Jakarta. Kemampuannya di bidang seni dan budaya terus diasah sehingga mendapat kepercayaan juga menjadi Tim Sutradara Pergelaran Pesona Madura dari Pemekasan untuk disajikan di Taman Mini Indonesia Indah, Jakarta. Tahun 2002, ia terpilih sebagai sutradara pelaksanaan upacara Mata Teguk di Pamekasan, Madura. Tahun 2002 juga, ia ditempatkan sebagai Tim Pelaksana Rokat Pandhabha dalam Festival Upacara Adat di Sidoarjo, Jawa Timur. Festival tersebut mengantar Kabupaten Pamekasan meraih juara I Se-Propinsi Jawa Timur. Sejak tahun 1985, ia juga terhitung aktif menjadi tim Pekan Olah Raga dan Seni Tingkat Sekolah Dasar dan Sekolah Menengah Pertama dan mewakili Kabupaten Pemekasan hingga ke tingkat Propinsi Jawa Timur. Sejak tahun
2013/2014, ia ditunjuk oleh Dinas Pendidikan Provinsi Jawa Timur menjadi Tim Penulis Buku Sekkar Assre (Bahasa Madura untuk Tingkat Sekolah Dasar Kelas II-VI). Dalam paparan Sekkar Assre itu tersurat materi pembelajaran Mamaca yang berpola tembang pangkur disertai notasi musiknya. Syair gubahannya itu mengetengahkan kearifan yang dinasihatkan atau sebagai tuntunan hidup bermasyarakat.

\section{Pelestarian dan Pengembangan Mamaca}

Pelestarian berarti pewarisan atau transmisi nilai-nilai seni dan budaya tradisional agar dapat diketahui oleh generasi kini maupun generasi akan datang. Pewarisan bukan berarti 'mengawetkan', tetapi merawat, merevitalisasi, dan mereaktulisasikan bentuk kesenian yang 'adi luhung' agar dapat terus diketahui oleh generasi sesuai zaman setempat. Proses pelestarian tampaknya bisa terwujud lebih intens lewat pendidikan informal, seperti di lingkungan rumah atau di keluarga dan di lingkungan masyarakat. Di lingkungan keluarga, pada umumnya, pewarisan nilai terjadi dari orang tua kepada anak, baik langsung maupun tidak langsung. Pematangan dan pemantapan transformasi nilai seni maupun budaya menjadi teruji

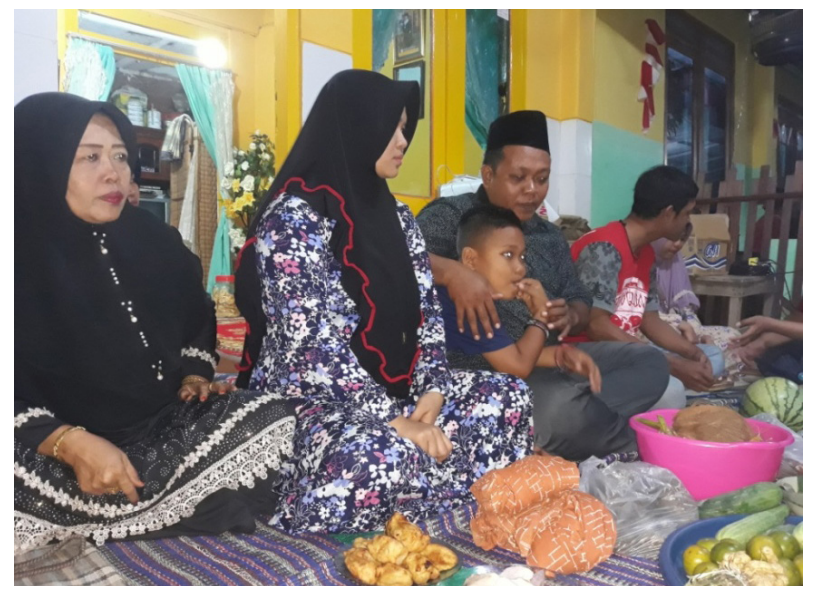

Gambar 3. Tampak keluarga Buhari Muslim duduk di depan sesaji ruwatan dari kanan ke kiri (Nyonya Buhari Muslim (55 th), Tri Yuni Wulandari (23 th), Hendra Prajayadi (32 th), Agus Ariyanto (29 th) menyaksikan kelompok seni Mamaca mengumandangkan syairsyair Mamaca yang diambil dari teks cerita Pandawa. (Dokumentasi: I Wayan Dana dan Supadma, 21 Juni 2019) 
kematangannya di masyarakat. Saluran pewarisan nilai-nilai kesenian di masyarakat bisa melalui berbagai wadah kegiatan, di antaranya berbentuk organisasi/kelompok kesenian atau sanggar-sanggar kesenian.

Pewarisan itu juga bermaknakan pelestarian kesenian tradisional, khususnya sebagai 'pusaka budaya', sehingga kesenian ini terus dikenal oleh generasi penyangga berikutnya. Generasi kini sebagai generasi penerus kesenian tradisional, seperti Mamaca, memiliki hak dan kebebasan untuk menginterpretasikan kembali tradisi yang mereka terima sesuai dengan jiwa zaman setempat. Artinya, sejarah mencatat bahwa tradisi itu senantiasa hidup di setiap generasi penerimanya berdasarkan pola pikir, pola perilaku, pola nilai yang melingkupi di lingkungan etniknya, sesuai kearifan budaya lokalnya. Stephen K. Sanderson (1993) mengedepankan jika terjadi perubahan infrastruktur, seperti kemajuan teknologi, ekonomi, dan lingkungan, hal itu akan mempengaruhi pula struktur sosial. Struktur sosial, seperti umpamanya pendidikan, organisasi sosial, perbedaan tugas/ kerja, tentu akan mempengaruhi jalannya superstruktur (ideologi). Hal ini pula yang menjadikan kesenian tradisional di masa lalu (zaman kerajaan) berbeda dengan zaman sekarang. Eksistensi ini menunjukkan bahwa seni tradisi itu hidup karena masyarakat sebagai penyangga budaya seni tradisional berikutnya mempunyai hak dan peluang untuk menggerakkan, mengembangkan, dan menciptakan seni tradisi Mamaca yang senantiasa berpijak pada akar budayanya dan tidak kehilangan makna atau rohnya.

Jadi, untuk menjaga keberlanjutan seni tradisi Mamaca dibutuhkan strategi pelestarian agar tetap diminati oleh lingkungan anak-anak maupun generasi muda masa kini. Teknologi sebagai alat dapat digunakan seoptimal mungkin untuk merekam proses pembelajaran Mamaca. Sajiannya digarap dalam bentuk koreografi kelompok yang variatif sesuai dengan dunia anak atau pelakunya.

\section{Strategi Pengembangan Mamaca di Pamekasan Madura}

Kenyataan menunjukkan bahwa generasi kini (anak-anak maupun dewasa) di Pamekasan, Madura, tampak memiliki jarak untuk mempelajari seni Mamaca. Namun, H. Sastra melalui kelompok Rukun Sampurna terus berupaya untuk mengenalkan dan mengajarkan seni Mamaca dengan berbagai cara serta kesempatan agar Mamaca bisa terus dikenal di lingkungan masyarakat Pamekasan. Kelompok Rukun Sampurna menjemput anak-anak seusia Sekolah Dasar dan Sekolah Menengah Pertama di lingkungan Desa Jalmak, Kecamatan Pamekasan, untuk diajak berlatih Mamaca bersama.

Saat melakukan studi lapangan pada hari Kamis-Sabtu, 9-11 Agustus 2018 di Pamekasan, Madura, H. Sastro berserta kelompoknya berkesempatan mengundang dan menghadirkan lima orang anak di rumahnya. Pada kesempatan itu, terlihat hadir: Mohammad Faiq Fikri (12), Indra Radi Sutrisno (13), Noval Dwi Ramadhan (14), Fadly Ibroizin (14), dan Sri Utami (9) sebagai satu-satunya peserta putri. Kelima orang anak ini dikenalkan oleh H. Sastro kepada kelompok Rukun Sampurna agar bisa dibina untuk pelatihan keterampilan seni Mamaca gaya Pamekasan, Madura. Pada kesempatan itu, penulis ikut menyaksikan pelatihan 'dasar' Mamaca yang diajarkan langsung oleh $\mathrm{H}$. Sastro. Latihan ini didukung dan dimotivasi oleh anggota kelompok Rukun Sampurna yang hadir pada hari Jumat, 10 Agustus 2018, dimulai malam hari sejak pukul 19.00-22.00 WIB.

Latihan dimulai dengan menyanyikan lagu-lagu dolanan yang populer dan dikenal di lingkungan anak-anak di Pamekasan, Madura. Selanjutnya, H. Sastro tetap mencoba dengan metode imitatif untuk mengumandangkan tembang pucung slendro pathet songo, bait demi bait yang langsung ditirukan oleh anak-anak. Tampak anak-anak dengan susah payah dan secara sungguh-sungguh menirukan lirik yang 
diucapkan oleh H. Sastro. Namun, H. Sastro juga berusaha secara berulang-ulang untuk membenahi nada-nada atau suara anak-anak yang tidak sesuai dengan yang diucapkan atau ditembangkan H. Sastro. Secara berulangkali, anak-anak juga menyanyikan dengan suara fals atau blero dan menirukannya dengan tidak sesuai seperti yang dicontohkan oleh $\mathrm{H}$. Sastro. Artinya, saat pelatihan Mamaca dengan metode imitatif, para peserta latihan belum mampu mengucapkan tinggi-rendah nadanada sesuai yang dikumandangkan pelatihnya, baik yang mencontohkan $\mathrm{H}$. Sastro maupun $\mathrm{H}$. Suparno (Observasi, 10 Agustus 2018 di Desa Jalmat, Pamekasan, Madura).

Pelatihan Mamaca, selain melalui metode imitatif, secara bersamaan disampaikan pula lewat metode baca notasi. Sebelum membaca bait-bait kalimat lagu, didahului dengan membaca notasi Kepatihan sehingga peserta latihan memiliki kecerdasan 'rasa' dengan mampu mengucapkan bait-bait lagu berdasar bacaan notasinya. Hal ini juga tampaknya tidak mudah diterapkan kepada anak-anak yang baru tahap awal pengenalan seni Mamaca. Memang untuk menuju ke tahap mahir melagukan Mamaca diperlukan ada pelatihan-pelatihan secara kontinu. Namun, disebutkan pula oleh H. Sastro maupun H. Suparno bahwa anak-anak kini tidak semuanya memiliki waktu khusus untuk tekun menjalani proses pembelajaran seni Mamaca. Tampak bahwa berbagai kendala menghadang untuk mengembangkan dan meregenerasi seni Mamaca di Pamekasan, Madura. Berbagai kendala tersebut di antaranya terkait dengan minat atau kurangnya keingintahuan belajar Mamaca bagi anak-anak di Pamekasan.

Generasi para pelaku seni Mamaca yang ada hingga keberlangsungannya saat ini memang dijalankan dengan mengalir sedemikian rupa sesuai bakat dari orang tua ke anak-cucu secara turun-menurun. Diketengahkan oleh Mariamah (38) bahwa ia bisa mengenal dan menguasai seni Mamaca karena biasa diajak menjadi 'waranggono atau nyinden' oleh kakeknya, Pak Artam, yang berguru dari Pak Marshum (wawancara, 10 Agustus 2018 bertempat di rumah H. Sastro). Menyimak dari berbagai informasi, wawancara, dan menyaksikan langsung proses pelatihan seni Mamaca, tampaknya memang belum terjadi proses pembelajaran seni Mamaca secara sadar dan sungguh-sungguh. Di samping itu, anak-anak masih belum mampu untuk melihat atau memperoleh manfaat dari belajar Mamaca. Dengan demikian, perlu waktu dan strategi atau upaya yang 'jitu' untuk melibatkan berbagai unsur, baik dari potensi masyarakat pencinta Mamaca, pemerintah setempat, unsur perguruan tinggi seni, maupun pihak sponsor atau industri.

\section{Penutup}

Untuk menjaga keberlanjutan setiap karya seni pertunjukan tradisional, termasuk sastra di dalamnya, yang biasanya memiliki dimensi filosofis dan sosiologis tertentu diperlukan strategi serta proses pembaharuan sesuai kultur masyarakat setempat. Meski di antara karya-karya sastra itu tidak murni lahir dari daerah setempat, ia berfungsi secara didaktis menjadi pedoman moral bagi masyarakat penyangganya. Hal ini terjadi pada seni tradisi Mamaca yang hingga saat ini masih bertahan di Madura, terutama di daerah Sumenep dan Pamekasan.

Sastra lisan ini memang tidak lahir dari rahim masyarakat Madura sendiri. Akar geneologisnya bisa dilacak pada tradisi macapat yang ada di Jawa yang sudah eksis sejak era Kerajaan Mataram. Tradisi macapat sendiri berasal dari tradisi Hindu-Jawa, yang secara terus menerus mengalami perkembangan sesuai jiwa zaman setempat. Demikian pula yang terjadi di Pamekasan Madura pada umumnya, kesenian ini dilakukan oleh generasi tua. Kini, kesenian ini perlu mendapat perhatian, baik dari pihak seniman pelaku Mamaca, pemerhati atau pencinta Mamaca, maupun lembaga atau pemerintah setempat yang memiliki wewenang untuk pemajuan seni dan budaya lokal di Pamekasan Madura. 
Lambat laun, nilai-nilai kesusastraan Mamaca yang animistik mengalami perubahan ketika Islam mulai masuk ke tanah Jawa. Pada akhirnya, dimensi filosofis-transendental khas Islam (seperti ajaran keagamaan, anjuran membenahi ilmu pengetahuan, dan memperbaiki moral) merasuk menjadi core values dalam Mamaca dan menjadi tata acuan bagi masyarakat dalam rangka mengarungi dramaturgi kehidupan.

\section{Kepustakaan}

Akhyar, Arif etal., 2010, Ensiklopedi Pamekasan: Alam, Masyarakat, dan Budaya, Klaten: PT Intan Sejati.

Buwono X, Hamengku. 2011. Ajaran Sang Amurwabumi: Sumber Acuan Nilai-Nilai Pendidikan Karakter Bangsa. Pidato Penganugerahan Gelar Doctor Honoris Causa Bidang Seni Pertunjukan pada Institut Seni Indonesia Yogyakarta.

Bouvier, Hélène, 2002. Lebur: Seni Musik dan Pertunjukan dalam Masyarakat Madura. Terj. Rahayu S. Hidayat. Jakarta: Yayasan Obor Indonesia.

Dana, I Wayan, dan AM Hermien Kusmayati, 2018. "H. Sastro: Penjaga dan Penggerak Mamaca di Pamekasan Madura", dalam Resital Jurnal Seni Pertunjukan vulome 17 No. 2-Agustus 2018 dan Ni Nyoman Sudewi dan Yohana Ariningtyas. 2014. "Kesenian dan Identitas Budaya: Kesenian Dusun Tutup Ngisor Memaknai Tradisi dan perubahan" [Laporan Penelitian Hibah Strategi Nasional]. Jakarta: DP2M Dikti dan I Made Arista. 2012.

"Menelusuri Akar Multikulturalisme di Indonesia Melalui Rajutan Kesenian" [Laporan Penelitian]. Denpasar: UNHI dan Ni Nyoman Sudewi. 2010.

"Pelestarian dan Perkembangan Tari Tradisi Bali: Studi Kasus Legong Kraton Peliatan" [Laporan Penelitian Hibah Fundamental]. Jakarta: DP2M Dikti ,2005, "Tayub Madura Pusaka
Budaya yang Memikat" dalam Dewa Ruci Jurnal Pengkajian \& Penciptaan Seni, Surakarta: Pascasarjana STSI Surakarta 2004, "Dramatri Topeng Madura dalam Balutan Modernitas" dalam Bunga Rampai Seni Tradisi Menantang Perubahan, Padangpanjang: STSI Padangpanjang Press. 2001, "Pertunjukan Kerapan

Sapi di Madura: Suatu Pelestarian yang Dinamis" dalam IDEA Jurnal Ilmiah Seni Pertunjukan, Yogyakarta: Fakultas Seni Pertunjukan ISI Yogyakarta.

Hadi, Y. Sumandiyo. 2011. "Revitalisasi Seni Pertunjukan Tradisi Sebagai Salah Satu Penguatan Identitas bangsa", makalah Seminar Nasional Dies Natalis ke-27 Institut Seni Indonesia Yogyakarta 4 Juni 2011, Yogyakarta.

Kementerian Pendidikan Nasional, 2011, "Desain Induk Pendidikan Karakter Kementerian Pendidikan Nasional", Jakarta: Kemdiknas.

Kusmayati, A.M. dan Suminto A. Sayuti, 2014, "Eksistensi Sastra Lisan Mamaca di Kabupaten Pamekasan, Madura" dalam Litera, vol. 13 no. 1, April 2014, jurnal FBS UNY, 182 - 190.

Kusmayati, A.M. Hermien dan Suminto A. Sayuti. 2010. "Perkembangan Seni Pertunjukan di Madura: Upaya Menegakkan Tradisi dan Ekonomi" [Laporan Penelitian]. Jakarta: DP2M.

Kusmayati, A.M. Hermien. 2006. Aspek Etika dalam Bingkai Estetika. Pidato ilmiah Pengukuhan Guru Besar Institut Seni Indonesia Yogyakarta.

Kusmayati, A.M. Hermien, 2000, ArakArakan: Seni Pertunjukan dalam Upacara Tradisional di Madura, Yogyakarta: Yayasan untuk Indonesia.

Kuswarsantyo. 2014. Dialektika Seni Pertunjukan. Yogyakarta: Bale Seni Condroradono.

Morris, Desmond. 2002. People Watching. London: Random House. 1977. Manwatching: A Field 
Guide to Human Behavior. New York: Harry N. Abrams Inc.

Raditya, Michael HB. 2014. "Wayang Hip-Hop Hibriditas Sebagai Media Konstruksi Masyarakat Urban" dalam Jantra vol. 9 no. 2, Desember 2014: 107 - 119.

Sastra, H., 2016, Sekkar Assre. Bahasa Madura untuk Tingkat Sekolah Dasar Kelas II - VI. Rifai, Mien Ahmad. 2007. Manusia Madura:
Pembawaan, Perilaku, Etos Kerja, Penampilan, dan Pandangan Hidupnya seperti Dicitrakan Peribahasanya. Yogyakarta: Pilar Media.

Wibawa, Sutrisno. 2014. Filsafat Jawa sebagai Sumber Pendidikan Karakter. Pidato Pengukuhan Guru Besar dalam Bidang Ilmu Filsafat Jawa pada Fakultas Bahasa dan Seni Universitas Negeri Yogyakarta.

\section{Lampiran Proses Pelatihan Koreografi 'baru' Mamaca}

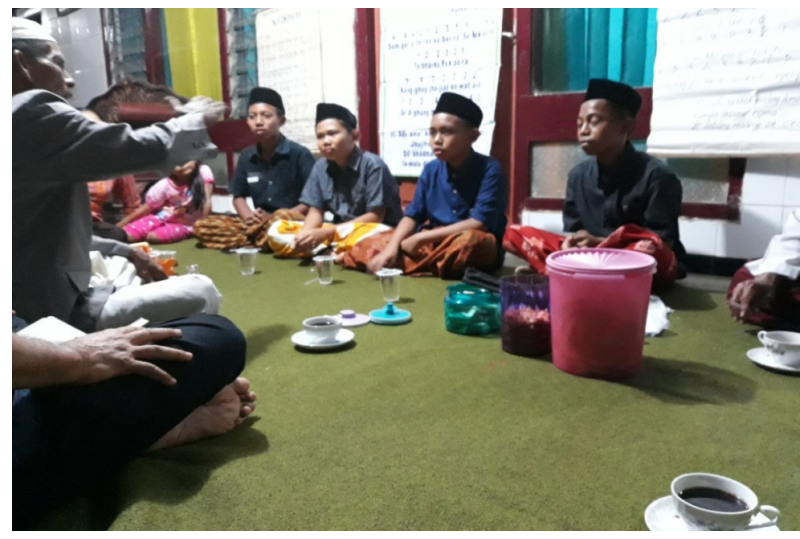

Gambar 1. H. Sastro memberi aba-aba (komando) agar menyamakan tinggi-rendah nada/suara dalam melagukan Mamaca secara bersamaan. (Dokumentasi: I Wayan Dana, 2019)

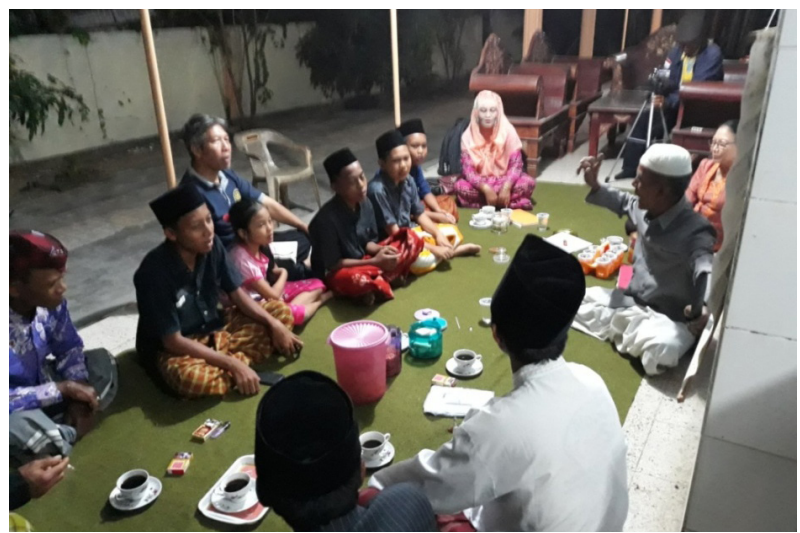

Gambar 2. Suasana H. Sastro mengajar Mamaca dengan metode 'Imitatif' (meniru) bertempat di serambi depan rumahnya. (Dokumentasi: I Wayan Dana, 2019)

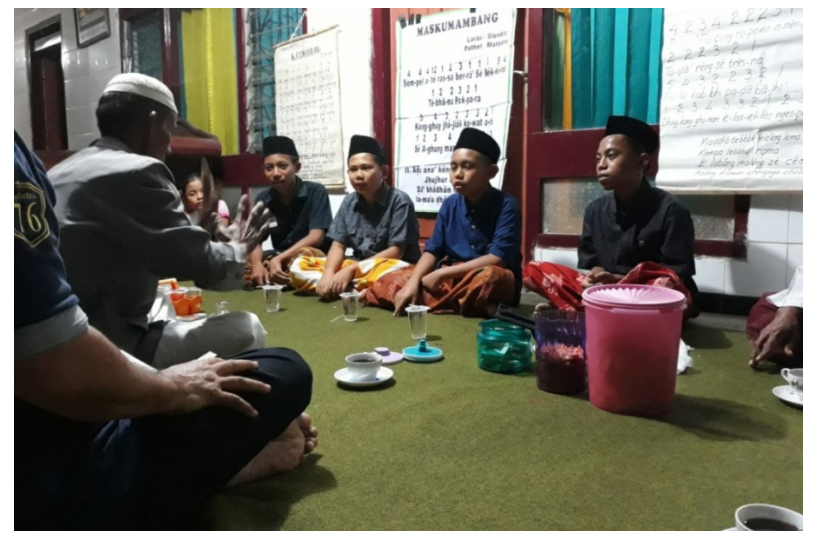

Gambar 3. Tampak kelompok anak-anak dengan serius mengikuti arahan H. Sastro dalam pelatihan

Mamaca. (Dokumentasi: I Wayan Dana, 2019)

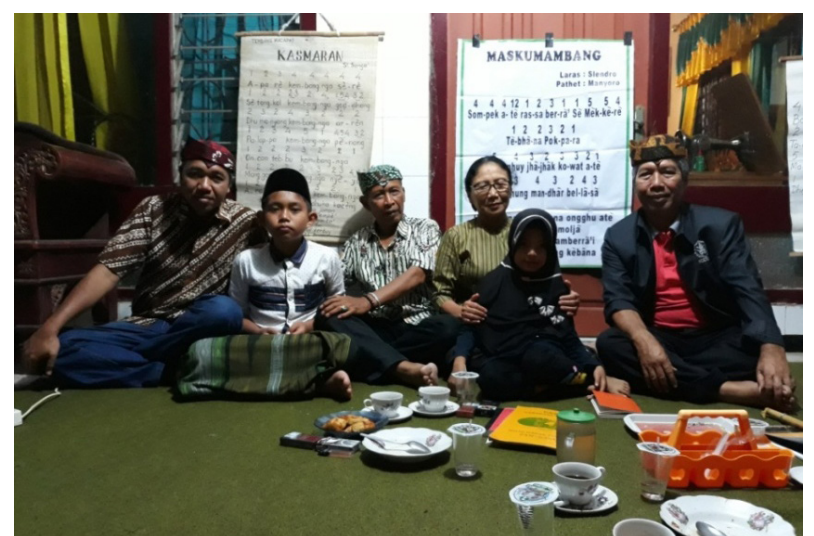

Gambar 4. Peserta anak-anak persiapan latihan bersama untuk regenerasi seni Mamaca di Pamekasan Madura. (Dokumentasi: I Wayan Dana, Agustus 2018) 